\title{
As línguas românicas do/no Magrebe: percurso histórico e presença contemporânea
}

\author{
Romance languages of/in Maghreb: \\ historical route and contemporary presence
}

Francisco Javier Calvo del Olmo

Universidade Federal do Paraná (UFPR), Curitiba, Paraná, Brasil.

franciscoctl.ctl@gmail.com

Resumo: Este artigo propõe-se reunir e examinar elementos que permitam traçar o percurso histórico das línguas românicas no Magrebe. Desde uma abordagem interdisciplinar, apresentam-se as comunidades latinizadas durante a dominação romana, os contatos linguísticos que produziram a Língua Franca mediterrânea no período medieval, as minorias de mouriscos e sefardim procedentes da Península Ibérica estabelecidas no norte da África nos séculos XIV e XV, o processo da colonização francesa nos séc. XIX e XX e o mosaico linguístico das últimas décadas, após a independência. Dessa forma, identificam-se os componentes linguísticos latinos e românicos, cindidos e descontínuos, constitutivos do Magrebe enquanto espaço geográfico, cultural e humano. Palavras-chave: Magrebe; línguas românicas; contato linguístico.

Abstract: This paper aims to gather and examine some elements to draw the historical course of the Romance languages in the Maghreb. It employs an interdisciplinary approach to present the Latinized communities during Roman domination, language contacts that produced the Mediterranean Lingua Franca during Middle Age, Moorish and Sephardic minorities settled in fifteenth and sixteenth centuries, the process of French colonization in nineteenth and twentieth centuries and the linguistic 
mosaic of last decades, after national independences. This itinerary permits to pinpoint a linguistic Latin-Romance component, fragmented and discontinuous, constitutive of the Maghreb as a geographic, cultural and human space.

Keywords: Maghreb; Romance languages; linguistic contact.

Recebido em 7 de maio de 2015.

Aprovado em 16 de julho de 2015.

\section{O Magrebe como espaço histórico: continuidade e cisões}

A geopolítica tende a estabelecer conjuntos de países e áreas que transcendem as meras fronteiras dos Estados-nação, blocos regionais que não respondem apenas a critérios geográficos, mas assumem uma série de caraterísticas sociais, culturais e históricas próprias, não isentas de assimetrias. Assim fazem parte de nosso imaginário espaços regionais tais como a América Latina, os Países Árabes, os BRICS, Médio Oriente, África Subsaariana, a Europa, o Sudeste Asiático, dentre outras. Além disso, é possível cindir cada uma dessas áreas em blocos menores: os países andinos, o Caribe, o Cone Sul, a Europa Mediterrânea, por exemplo. Dentro dos países árabes, pode se recortar uma área no ocidente formada pelos países litorâneos da África que ficam ao Oeste da Líbia: o Magrebe. ${ }^{1}$ Segundo Azouzi (2008, p. 39), Magrebe em árabe significa poente, por oposição a Maxerreque, ou sol nascente.

Após as independências (o Marrocos e a Tunísia em 1956 e a Argélia em 1962), as elites econômicas e políticas desses países procuraram na prática do Islã e no legado da língua árabe os fundamentos da identidade pós-colonial magrebina e, consequentemente, adotaram uma política de arabização com o objetivo de compensar e reverter o

\footnotetext{
${ }^{1}$ Mesmo fazendo parte da União do Magrebe Árabe, a Líbia ocupa uma posição de ponte entre o Maxerreque e o Magrebe. Curiosamente, na antiguidade, a linha que separava o Império Romano de Ocidente (cuja língua veicular era o latim) do Império Romano de Oriente (cuja língua veicular era o grego) atravessava o atual território líbio.
} 
processo de aculturação ${ }^{2}$ e assimilação imposto durante a dominação colonial; ou seja: "la dissolution dans la culture étrangère importée par la colonisation et perpétuée par les multiples échanges économiques et culturels avec le monde occidental"' (BENZAKOUR; GAADI; QUEFFÉLEC, 2000, p. 60). Desse modo, o discurso da arabização se instituiu sobre outros elementos profundamente enraizados na região tais como as africanidades, as culturas berberes ou a presença secular latina.

Porém, Frantz Fanon (1963, p. 52) escrevia que a cultura aborrece a simplificação enquanto Bourdieu (2012) recordava como o califa Omar brincava com a raíz frq, que em árabe significa divisão, e que coincide com as consonantes de Ifriqiya, nome usado também para designar o Magrebe:

"L'Afrique (du Nord), c'est le fractionnement !" Telle est bien l'apparence que proposent le passé et le présent du Maghreb. Diversité ou unité ? Continuité ou contrastes ? À ne retenir que les différences, ne risque-t-on pas de laisser échapper l'identité profonde?"4 (BOURDIEU, 2012, p. 7).

Avançando em sua argumentação, este autor aponta que unidade e pluralidade, continuidade e divisão, representam aspectos antitéticos que precisam um do outro para determinar seus significados; assim define o Magrebe como espaço de confrontação entre elementos culturais diversos de onde emerge uma civilização magrebina original em contínua interação: "Il n'est pas au Maghreb de monde clos et partant, pur et intact; pas de groupe si isolé, si replié sur soi qui ne se pense, ne se juge en référence à des modèles étrangers" ${ }^{5}$ (BOURDIEU, 2012, p. 9).

Dentro do espaço que sucintamente recortamos, tentaremos examinar, nas próximas seções do artigo, a presença de núcleos falantes

\footnotetext{
${ }^{2}$ Isto é, a dissolução da cultura local na cultura estrangeira importada pela colonização e perpetuada através das múltiplas trocas econômicas e culturais com o mundo ocidental. ${ }^{3}$ A dissolução na cultura estrangeira importada pela colonização e perpetuada pelos múltiplas trocas econômicas e culturais com o mundo ocidental.

4 “A África (do Norte) representa a cisão!” Esse é exatamente o aspeto que apresenta o passado e o presente do Magrebe. Diversidade ou unidade? Continuidade ou contrastes? Se só retivermos as diferenças, não corremos o risco de deixar escapar uma identidade profunda?

${ }^{5} \mathrm{O}$ Magrebe não é um mundo fechado, puro e intato; não tem nenhum grupo isolado e ensimesmado o suficiente para não pensar-se e julgar-se em referência a modelos estrangeiros.
} 
de diversas variedades de latim ou de línguas românicas no vasto eixo temporal de dois milênios, as complexas relações que esses elementos latinos estabelecem com as línguas berberes e o árabe dialetal, assim como sua vigência integrada em uma identidade magrebina plural.

\section{O percurso do latim na África: auge, declive e previdência}

De acordo com Fanciullo (1986, p. 163), a presença do latim na franja litorânea do Norte da África, isto é, no Magrebe, ocorreu como resultado das Guerras Púnicas, séc. III e II a.C., nas quais Roma e Cartago disputaram o controle do Mediterrâneo ocidental. Ao final da terceira Guerra Púnica, a cidade de Cartago foi destruída e o poder romano estabeleceu a proibição de habitar aquele lugar até que em 29 a. C. o imperador Augusto refundou a cidade chamando-a Colônia Julia Cartago. Deste modo, a região, dividida nas províncias de África Proconsularis, Mauretania Caesarensis, Tingitana e Numidia, se tornou um área central do orbe romano. O latim suplantou o púnico, a língua de Cartago, como idioma hegemônico na região e se difundiu gradativamente desde os centros urbanos. Já ao Oriente, na província da Cirenaica, começava o território onde o grego era a língua veicular de acordo com Tagliavini (1993, p. 250). Porém, parte da população africana resistiu à assimilação cultural com sucesso:

En la costa septentrional de África había una población indígena, semicivil, que resistió a la asimilación romana, como más tarde a la árabe. Se trata de la población que los antiguos llamaron "líbica" y que hablaba un idioma perteneciente a la familia camítica; dicha población se prolonga directamente en los modernos bereberes, cuyos dialectos, esparcidos por el África septentrional en grupos discontinuos, se extienden de la costa atlántica $[\ldots]$ hasta el oasis de Siwah en Egipto (TAGLIAVINI, 1993, p. 251). ${ }^{6}$

\footnotetext{
${ }^{6}$ No litoral setentrional da África havia uma população indígena, semicivil, que resistiu à assimilação romana, e mais tarde à árabe. Trata-se da população que os antigos chamaram de "líbica" que falava um idioma pertencente à família camítica; essa população se prolonga diretamente nos modernos berberes, cujos dialetos, espalhados pela África setentrional em grupos descontínuos, abrangem da costa atlântica [...] até o oásis de Siwah no Egito.
} 
O cenário linguístico que foi aqui desenhado não devia ser muito diferente ao de outras províncias como a Hispânia ou a Gália; e ele deve ter mantido certa continuidade apesar do colapso do império e as lutas entre vândalos e bizantinos pelo controle dos territórios africanos. Porém, a expansão do Islã interrompeu o processo de romanização; Cartago foi tomada pelos muçulmanos em 698 e, embora o império bizantino conseguisse recuperar a cidade, em 705 um novo ataque muçulmano a reduziu a cinzas, como séculos atrás os mesmos romanos tinham feito com a Cartago púnica. Finalmente, os exércitos enviados desde o Califado Omíada de Damasco consolidaram o domínio do Islã. Inicia-se então a paulatina conversão ao Islã e a arabização das tribos berberes e da população norte-africana latinizada e cristianizada. Esse processo pode-se sintetizar em duas fases:

(i) século VII a XI, em que o árabe só domina nas cidades (Fès, Kairouan, Tlemcen); (ii) do século XI ao XIII, em que se dá a invasão dos hilalianos, que completa o processo de arabização de toda a região. Com isso, esboça-se o que serão os dialetos árabes da região do Maghreb (árabe beduíno) (COUTO, 2002, p. 25).

Entretanto, a chegada do Islã não provocou o desaparecimento automático nem do latim africano nem da população cristã; originando um panorama ecolingüístico de enorme complexidade:

La situazione etnico-linguistico-religiosa dell'Africa settentrionale dopo la conquista araba si presenta troppo complessa perché non sia lecito sospettare, dietro la definizione di 'barbari', gruppi di romanzofoni ma anche di berberofoni e perfino di grecofoni, indipendentemente dalla religione professata; o non si possano ammetere, eventualmente, nuclei di cristiani arabofoni(FANCIULLO, 1986, p. 164). ${ }^{7}$

\footnotetext{
${ }^{7}$ A situação étnico-linguístico-religiosa da África setentrional após a conquista árabe apresenta enorme complexidade e é lícito a hipótese da existência, atrás da definição de 'bárbaros', de grupos de falantes de variedades românicas e também de falantes de berbere e inclusive de falantes de grego, com independência da religião que professassem; ou admitir, eventualmente, a existência de núcleos de cristãos falantes de árabe.
} 
Esta latinidade autóctone africana não deixou documentos escritos; no entanto, existem indícios históricos e epigráficos que permitem pensar que a língua se manteve durante a Alta Idade Média, provavelmente em forma de variedades neolatinas locais. Primeiramente, as inscrições dos cemitérios cristãos de Fondúgh el Maggúz e de Ain Zara, ambos os dois próximos a Trípoli, testemunham uma tradição epigráfica em latim mantida, pelo menos, até o séc. IX. Fanciullo (1986, p. 163164) explica que as hipercorreções e os erros que contêm esses epitáfios escritos em latim requisitam ser explicados dentro de um contexto de diglossia latino-românica. Em segundo lugar, os empréstimos linguísticos latinos e românicos integrados fonética e morfologicamente em vários idiomas da família berbere e nos dialetos do árabe magrebino, assim como nos topónimos e antropónimos locais completam as informações que as inscrições oferecem para reconstruir a fisionomia do latim africano. Por último, o geógrafo árabe Al-Idrisi, que escreve no séc. XII, informa da existência na cidade de Gafsa, no sul da Tunísia, de ar-Rüm al-Afāriqa, romanos africanos, falantes de al-lat.īni al-ifrìq $\bar{l}$, ou seja, latim africano. Nesse mesmo período, a exígua população cristã norte-africana apoiou a conquista normanda de Roger II de Sicília do litoral tunisino, de acordo com Abulfia (2014). Em todo caso, a breve vida do Reino Normando da África, de 1135 a 1160, e as possíveis represálias das autoridades muçulmanas, uma vez recuperado o território, sobre a população cristã, e talvez latina, pôde acelerar o desaparecimento das variedades românicas locais, seguramente antes do final da Idade Média.

Deste modo, salienta-se como as línguas românicas seguem trilhos divergentes na margem norte e sul do Mediterrâneo; as línguas neolatinas são adotadas nas chancelarias dos reinos europeus no séc. XII e começam então a afirmar-se como línguas de cultura frente ao latim, enquanto que as variedades africanas, agonizam em núcleos cada vez mais reduzidos e isolados até se extinguirem. Por esse motivo, a linguística românica classificou as antigas províncias africanas dentro da Romania Submersa, ou seja, dos territórios onde o latim não teve continuidade (RENZI, 1982; TAGLIAVINI, 1993; POSNER, 1998). Em contraste com essa tese geralmente aceita, devemos considerar que o declive da latinidade norte-africana coincide com a instalação no Magrebe de novas populações romanófonas. A chegada dos judeus sefardim e os mouriscos expulsos de Castela, Aragão e Portugal, o florescimento do comércio com as cidades da Itália e as conquistas militares de enclaves litorâneos pelos 
reinos cristãos são fatos que renovaram a presença das línguas românicas na região durante a Idade Moderna.

\section{Minorias e línguas em contato: das Cruzadas ao fim do $\mathbf{A n}$ - cien Régime}

A partir do século XV, diferentes Estados da margem norte do Mediterrâneo estabeleceram colônias e enclaves comerciais em pequenas ilhas e praças fortificadas do litoral magrebino. Em 1415, João I de Portugal conquista Ceuta e, nas décadas seguintes, os portugueses se apoderam de Alcácer-Seguir, Tanger, Arcila, Mazagán, Safi e Agadir; só a derrota na batalha de Alcácer-Quibir, em 1578, deteve seus interesses expansionistas. A maioria desses enclaves passou depois às mãos da Coroa Hispânica que já tinha conquistado Melilha em 1497 e Orã em 1509. Em 1540, a família genovesa dos Lomelli instala na ilha de Tabarka, perto de Túnis, uma colônia dedicada à pesca de coral. Anteriormente, a ilha de Djerba, também próxima à Tunísia, tinha sido conquistada pelo almirante aragonês Roger de Lauria e é precisamente nessa ilha onde se compõe, em 1284, o poema satírico o Contrasto della zerbitana, considerado hoje o primeiro testemunho da Língua Franca.

A Língua Franca representa um fenômeno bastante complexo e deve ser considerada como o pidgin usado nos portos do Mediterrâneo desde a Idade Média até o século XIX como veículo de comunicação entre populações da margem sul - principalmente árabes, turcos e berberes - e da margem norte - falantes de idiomas neolatinos: genoveses, venezianos, pisanos, catalães, espanhóis, franceses, portugueses entre outros -. Concomitante, escritores de diferentes nacionalidades usaram a Língua Franca para caracterizar personagens e representar ou caricaturar certa imagem de oriente.

Sur une grande partie des pourtours méditerranéens, dont les côtes de l'Italie, de la France, de l'Espagne et du Maghreb, la lingua franca fut en usage, durant tout le Moyen Âge, l'époque classique, et jusqu'au début du XIXe siècle, dans les relations commerciales, politiques, diplomatiques ou guerrières qu'eurent avec les Français les souverains d'Alger et de Tunis, ainsi que les marchands et voyageurs, militaires et marins. La dynamique de ces rapports assez instables, et sans doute aussi le caractère 
coloré et pittoresque d'un sabir où se mélangeaient des mots d'origines hétéroclites (surtout italiens, mais aussi provençaux, catalans, castillans, français, grecs, turcs et arabes) firent de la lingua franca un sujet de fantaisies littéraires, comme il en apparaît dans les pièces de Goldoni, Calderón, et, chez Molière, dans la célèbre turquerie d'une des scènes du Bourgeois gentilhomme (HAGËGE, 2000, p. 154$){ }^{8}$

Observa-se assim que a Língua Franca foi usada durante o longo período que une a Baixa Idade Média e as vésperas da colonização francesa, no séc. XIX; mas cabe se questionar quando e sob quais circunstâncias teria se originado. As Cruzadas têm um papel importante no seu surgimento e, de fato, os povos orientais chamavam aos povos da Europa ocidental de francos: por 'franco' entendiam "o modo como os europeus se comunicavam" (COUTO, 2002, p. 16) e assim o termo árabe lisān-al-faranğ $\bar{l}$ designava o idioma dos francos. $\mathrm{O}$ mesmo autor afirma que "de acordo com o bizantino Joannes Tzetzes, por volta do séc. XII a comunicação entre 'latinos' (ocidentais) e bizantinos se dava em latim" (COUTO, 2002, p. 39). Deste modo, podemos conjeturar a existência de um latim comercial simplificado, do qual a Língua Franca seria continuadora; mesmo carecendo no momento atual de documentos suficientes para prová-lo, "as atividades dos romanos, levando alguma variedade de sua língua para diversas partes da região, deve ter pelo menos contribuído para a preparação do terreno ao advento da LF" (COUTO, 2002, p. 23). Portanto, o surgimento da Língua Franca enlaça com o latim usado por comerciantes da Alta Idade Média que, por sua vez, estabelece continuidade com o latim implantado nas províncias africanas durante o Império.

\footnotetext{
${ }^{8}$ Em boa parte da bacia mediterrânea, compreendendo o litoral da Itália, da França, da Espanha e do Magrebe, a língua franca esteve em uso, durante toda a Idade Média, a época clássica até o começo do séc. XIX, nas relações comerciais, políticas, diplomáticas ou bélicas que tiveram com os franceses os soberanos de Argel e Túnis, assim como com os mercadores e viajantes, militares e marinheiros. A dinâmica dessas relações bastante instáveis, e também o caráter colorido e pitoresco de um sabir que misturava palavras de origens heteróclitos (principalmente italianas, mas também provençais, catalãs, castelhanas, francesas, gregas, turcas e árabes) fizeram da lingua franca sujeito de fantasias literárias, como aparece nas peças de Goldoni, Calderón, e, no caso de Molière, na célebre cena do turno no Bourgeois gentilhomme.
} 
Quanto à sua composição, a Língua Franca variava segundo o lugar e a época, mas o núcleo léxico principal era essencialmente românico com predominância de elementos vênetos, genoveses e aportes do toscano, castelhano, catalão, siciliano, occitano, francês e português, bem como de outras línguas não latinas: grego, turco e árabe. A respeito da sua implantação geográfica, devia abranger praticamente a totalidade dos portos da bacia mediterrânica; porém, nas cidades magrebinas de Argel, Túnis, Trípoli e Orã teve uma presença mais maciça e duradoura. O frei beneditino Diego de Haedo descreveu a Argel do século XVII como um espaço plurilíngue onde coabitava o turco, o árabe dialetal e clássico, o cabila (língua berbere) e a própria Língua Franca que ele denomina modo de hablar christiano. No entanto, nunca alcançou esferas prestigiadas ou oficiais e "mesmo em Argel, a Língua Franca era mera língua auxiliar, meio precário de comunicação entre falantes de línguas mutuamente ininteligíveis" (COUTO, 2002, p. 21).

A Língua Franca se une a outras formas de expressão linguística e outras produções textuais românicas praticadas por comunidades estabelecidas no Magrebe durante a Idade Moderna. Neste ponto devemos apresentar a aljamia, palavra que serve para designar os textos escritos em espanhol usando o alfabeto árabe, produzidos por muçulmanos que moravam nos territórios cristãos da Península Ibérica entre os séc. XV e XVII, de acordo com Bouras (2009, p. 74). A população muçulmana que morava nos reinos cristãos da Península Ibérica (majoritariamente nos reinos de Aragão e Valência) foi obrigada a abraçar a fé cristã; mas, devido à desconfiança da nobreza e do clero, os membros dessa comunidade mantiveram uma identidade cultural diferenciada e receberam o nome de mouriscos (moriscos em espanhol e catalão). Durante todos os séculos que durou a presença muçulmana em Al-Ândalus os intercâmbios de população entre a Península Ibérica e o Magrebe tinham sido constantes, mas entre 1609 e 1616 essa ingente comunidade $^{9}$ viu-se obrigada a atravessar o Estreito de Gibraltar quando Felipe III decretou a sua expulsão definitiva. O impacto da chegada dessa população no Magrebe possui enorme quantidade de elementos que podem ser analisados desde diversas perspectivas e enfoques. Aqui só apontaremos que uma parte deles foi para as áreas rurais e introduziu

\footnotetext{
${ }^{9}$ Couto (2002, p. 25) estima entre 150.000 e 900.000 o número total de mouriscos ou muçulmanos que retornam para o norte da África.
} 
novas culturas e técnicas agrarias, enquanto outros se instalaram em cidades como Fez, Tetuão, Rabat, Chauen e Orã fundando bairros e influindo nas dinâmicas econômicas, políticas e culturais da região. Muito provavelmente, as primeiras gerações conservaram a língua trazida da península já que o conhecimento do árabe devia ser precário para muitos; posteriormente ela, ou algumas das suas palavras e expressões, pôde se manter nessas comunidades como vínculo que reforçava os laços entre os membros. Epalza e Slama-Gafsi (2010, p. 144) assinalam que o uso do espanhol por mouriscos fabricantes de chechías, ${ }^{10} \mathrm{em}$ Túnis, servia para proteger os segredos da fabricação. De acordo com os mesmos autores, os mouriscos instalados no Magrebe abandonaram os nomes cristãos adotados no batismo - por nomes árabes; porém, muitos conservaram os sobrenomes hispânicos como sinal de identidade. Além disso, a literatura aljamiada, liberada da clandestinidade à qual foi exposta em território peninsular, floresceu no Norte de África, produzindo obras de diverso gênero. Entretanto, o árabe, língua do Islã, dominante em todas as esferas, exerceu pressão contra o uso da aljamia.

Os judeus sefardim, oriundos da Península Ibérica, seguiram um caminho análogo ao dos mouriscos. Expulsos dos Reinos de Castela e de Aragão em 1492 foram acolhidos pelo Império Otomano e se estabeleceram principalmente em cidades dos Bálcãs e na beira magrebina do Mediterrâneo. Essas comunidades mantiveram o uso do judeu-espanhol nas centúrias seguintes junto àlgumas tradições culturais peninsulares.

Se as práticas linguísticas românicas dos mouriscos acompanhavam uma tradição literária própria, a aljamia; o judeu-espanhol usado pelos sefardim encontra o seu reflexo no ladino. Este "no ha sido nunca una lengua hablada, sino la traducción "verbo a verbo" del hebreo o el arameo al español de textos bíblicos o de oraciones rituales"11 (ALVAR, 2000, p. 31). Nesse mesmo sentido, Hagège (2000, p. 275) classifica o ladino como língua de decalque, que toma a morfologia e a sintaxe do hebreu e o vocabulário da língua vernácula da diáspora, destinada só à tradução e leitura dos textos religiosos. Entretanto, nos séc. XVIII e XIX o judeu-

\footnotetext{
${ }^{10}$ Um tipo de barrete ou chapéu sem abas alargado para cima tradicionalmente usado no vestuário masculino magrebino.

${ }^{11}$ Nunca foi uma língua falada, mas a tradução "verbo a verbo" do hebreu ou do aramaico ao espanhol de textos bíblicos ou de orações rituais.
} 
espanhol chegou a ser usado em peças de teatro, cantigas populares e até publicações periódicas de acordo com as necessidades dos seus falantes.

Podemos conjecturar que o contato dos mouriscos e dos sefardim, instalados no Magrebe, com comerciantes, soldados, marinheiros e escravos procedentes da Espanha, deve ter contribuído para a conservação e renovação dos usos dessas línguas nos séculos que seguiram à expulsão.

Em síntese, observamos que, durante a Idade Moderna, se integram no espaço cultural, social e linguístico magrebino diferentes variedades românicas transplantadas desde a Romania Continua no Sul da Europa. Assim, nos portos magrebinos floresce a Língua Franca, pidgin de base léxica românica; enquanto núcleos de judeus sefardim e de mouriscos mantêm variedades ibéricas na comunicação ao interno da comunidade e recebem cultivo literário. Salienta-se a diferença entre a Língua Franca que serve como veículo de comunicação entre grupos étnicos distintos e as línguas dos sefardim e dos mouriscos, restritas aos âmbitos familiares ou comunitários. Por fim, as praças, ilhas e enclaves ocupados por Portugal, Espanha e Génova são pontos de difusão das línguas desses Estados, consolidadas a partir do séc. XV como línguas de cultura. Os empréstimos léxicos que transitam em ambos os sentidos dão testemunha desse cenário complexo e dinâmico onde as línguas majoritárias do Magrebe, árabe e berbere, coabitam com as línguas neolatinas, a língua do outro, por um período de mais de quatrocentos anos.

\section{O atual mosaico plurilíngue: colonização, línguas em contato e hibridação}

A penetração das potências europeias, inscrita no processo de colonização da África, alterará profundamente o cenário esboçado na seção precedente. Em 1830 a armada francesa desembarca na cidade de Argel e depõe a autoridade otomana; em seguida, a França ocupa a faixa litorânea argelina e avança para o Sul no deserto do Saara. Em 1881, se implanta em Túnis o protetorado francês enquanto em 1912 Paris estende o seu protetorado sobre a maior parte do Marrocos. Em menos de cem anos, a França consegue consolidar um sistema colonial na região. A sociedade magrebina se vê profundamente alterada no seu conjunto ao se integrar em um contexto que reposiciona o significado dos traços culturais locais. Os europeus transferidos para terras magrebinas criam um entorno familiar que reflete a própria imagem, como negação 
da fisionomia do país anterior a sua chegada. Destarte, o colonizado se torna um estrangeiro na própria terra, obrigado à escolha entre adaptarse aos padrões do colonizador ou manter-se fiel a sua própria cultura. Essa brecha permeia o conjunto da sociedade colonial, constituída como justaposição de duas comunidades de acordo com Bourdieu (2012, p.128). A comunidade europeia, formada pelo colonizador e os assimilados (minorité majoritaire), domina o plano social, cultural, econômico e político enquanto a comunidade formada pelas populações autóctones, árabes e berberes, fica marginalizada em todos os níveis.

No plano linguístico, Huchon (2002, p. 232) define a implantação no Magrebe como um dos acontecimentos marcantes da história do francês no curso do séc. XIX. Cabe salientar que o francês não se implanta ex novo no Magrebe, mas se apoia nas variedades românicas preexistentes; a Língua Franca, chamada pelos conquistadores de sabir, serve como primeiro canal para a comunicação entre colonizadores e colonizados; este pidgin irá se aproximando ao francês padrão, dando lugar a formas mais ou menos afastadas do bon usage metropolitano. Igualmente a Aliança Israelita Universal, fundada na França em 1860, exerce forte influência sobre as comunidades judias magrebinas que abandonam progressivamente o judeu-espanhol em favor do francês, língua detentora de maior prestígio. ${ }^{12}$ Por outro lado, o Magrebe se torna rapidamente um importante produtor de cultura e literatura em língua francesa com l'École d'Alger e o trabalho de intelectuais e escritores como Gabriel Audisio, Jean Amrouche, Emmanuel Roblès e a figura central de Albert Camus.

As mudanças que enunciamos se consolidam durante a primeira metade do séc. XX, mas os resultados da Segunda Guerra Mundial (momento em que Argel chegou a ser a capital da França liberada) e os processos de descolonização alteram de novo o mencionado entorno linguístico. Assim, a Argélia alcança a independência em 1962, após uma longa guerra de libertação; por sua vez, a Tunísia e o Marrocos já eram estados independentes desde 1956. Nesse momento, estes três países procuraram recuperar (ou construir) identidades nacionais promovendo a arabização, consoante com a prática do Islã e os valores patriarcais,

\footnotetext{
${ }^{12} \mathrm{O}$ decreto Crémieux aprovado em 24 de outubro de 1870 concedia a nacionalidade francesa aos quase quarenta mil judeus da Argélia, majoritariamente de origem sefardim, assimilados no cultural e no linguístico à nova metrópole.
} 
em detrimento de outros elementos culturais. Entretanto, a influência da colonização europeia se prolonga além da independência; fato que faz com que o Magrebe se apresente hoje como um mosaico linguístico marcado pela hibridação, onde várias línguas e dialetos coabitam com status desigual.

Primeiramente, os berberes, distribuídos em comunidades dispersas sobre o vasto espaço magrebino, conformam a população majoritária em algumas regiões como a Cabília argelina ou o Rif marroquino. Após as independências, a marginalização dessas comunidades nos novos estados-nação provocou o surgimento de movimentos que reivindicavam proteção e promoção das identidades berberes não isentos de conflito. Nos últimos anos ocorreram alguns avanços: a Argélia reconheceu o tamazight, língua berbere, como segunda língua nacional junto ao árabe em 2002 enquanto a nova constituição do Marrocos concedeu o status de língua oficial ao berbere em 2011.

Em segundo lugar, podemos entender a língua árabe, hegemônica no espaço magrebino, como o somatório de variedades e usos diferenciados. $\mathrm{O}$ árabe clássico, a língua do Alcorão e da liturgia no Islã, serve como base para o árabe moderno, língua oficial presente na imprensa e na mídia, na produção literária, audiovisual e científica assim como em todos os âmbitos do Estado (sistema educativo, judicial, forças armadas etc.). A política de arabização, empreendida pelas autoridades desde as independências, tem procurado estender o uso desse idioma a todos os setores sociais. Porém, este árabe moderno não é a língua materna nem cotidiana da população; quinze séculos de história da língua árabe em solo magrebino originaram um mosaico de variedades dialetais, chamadas de darija por seus próprios locutores. ${ }^{13} \mathrm{~A}$ darija muda de um país a outro assim como entre as cidades e regiões de cada país e entre os grupos sociais. O estabelecimento de três unidades nacionais - Argélia, Marrocos e Tunísia - tende a consolidar três variedades praticadas na vida pública de cada país: árabe argelino, árabe marroquino e árabe tunisino; diferenciadas, mas mutuamente inteligíveis.

Neste ponto devemos examinar o papel que os novos Estados independentes concedem à língua do colonizador, o francês. Azouzi

\footnotetext{
${ }^{13}$ Os dialetos magrebinos conformam um bloco frente aos dialetos do Maxerreque, resultado dos fenômenos que definem a composição linguística, histórica e cultural da região.
} 
(2008) explica a falta de consenso e a ambivalência das elites políticas e intelectuais argelinas, marroquinas e tunisinas após as independências a respeito do novo status da língua francesa, "tantôt contestée, tantôt adoptée", ${ }^{14}$ praticamente ausente nas constituições. Situação que perpetuou a penetração do francês graças à extensão da escolarização, a presença desse idioma na mídia e nos textos oficiais ${ }^{15}$ e ao seu papel dominante nas relações profissionais. Nas últimas três décadas do séc. $\mathrm{XX}$, aparecem novos fatores que dinamizam a presença meramente hereditária do francês no Magrebe: primeiramente, ele não é mais percebido como sinal da colonização, mas como uma língua de cultura, como um idioma internacional que possibilita maior abertura ao mundo; ao mesmo tempo, a maciça migração magrebina para a antiga metrópole reforça a prática desse idioma no seio das famílias que vivem repartidas entre as duas margens do Mediterrâneo; além disso, surge uma literatura magrebina de expressão francófona continuadora da literatura magrebina francesa do período colonial. Essas/es escritoras/es (argelinas/os, marroquinas/os ou tunisinas/os) compartilham um horizonte comum transnacional: o Magrebe. Em síntese, na atualidade, o Magrebe abriga a segunda comunidade francófona mais numerosa do mundo depois da França ${ }^{16} \mathrm{e}$ a língua aportada pelo colonizador se enraizou nas sociedades dos países independentes e entrou em um processo de vernacularização.

Nesse sentido é necessário esclarecer que a prática da língua francesa não é homogênea na região. Segundo Benzakour, Gaadi e Queffélec (2000, p. 84-113), existe uma variedade alta, variété acrolectal, conforme à norma culta do Hexágono, fonte de prestígio social, praticada pela elite. Em contrapartida, há uma variedade baixa, variété basilectale, usada por pessoas não ou pouco letradas que adquiriam alguns rudimentos de francês sur le tas. Por fim, existe uma variedade intermédia, variété mésolectale, difundida na mídia e usada pelos escritores francófonos que

\footnotetext{
${ }^{14}$ Por vezes contestada e por vezes adotada.

${ }^{15}$ Assim o Journal officiel de la République tunisienne (JORT), Bulletin officiel du Reyaume du Maroc (BORM) e o Journal officiel de la République algérienne démocratique et populaire (JORA) disponibilizam versões em francês com caráter informativo, tendo valor legal apenas a versão em árabe.

${ }^{16}$ As cifras da Organisation Internationale de la Francophonie (OIF) contabilizam 10 131000 de francófonos, totais ou parciais, no Marrocos (33\% da população total); 6360 000 na Tunísia (63.6\% da população) e 18000000 na Argélia (48\% da população). Os três países totalizam 34500000 milhões de francófonos (48\% da população magrebina).
} 
acompanha à expansão da classe média em detrimento da variedade alta e baixa. Este é um francês em contato linguístico que adquiriu formas locais e não se percebe hoje como língua estrangeira, mas como língua adotada e remodelada para responder às necessidades socioculturais do contexto magrebino. Cada variedade não forma um circuito fechado, isolado das outras, mas se integra em um continuum que vai do francês mais próximo ao padrão parisiense ao francês mais localmente marcado.

Por último, outras línguas europeias têm presença hoje em território magrebino. O espanhol está focalizado no norte do Marrocos, sustentado pelas relações históricas, os intercâmbios comerciais, a distribuição da mídia espanhola, os movimentos migratórios e a ação cultural hispano-marroquina. Além disso, a Espanha mantém duas cidades autônomas na costa africana: Ceuta e Melilha. A presença do italiano na Tunísia responde a razões análogas. Finalmente, o inglês como língua hegemônica global também irradia a sua influência na região.

Dentro do complexo mosaico linguístico apresentado, em que várias línguas convivem e concorrem entre si, parece lógico que tenham surgido formas de expressão híbridas. O bilinguismo maciço árabe-francês está na base do code mixting ou alternância entre os dois idiomas na conversa informal das grandes cidades magrebinas, onde confluem o árabe dialetal urbano, repleto de empréstimos franceses, e o francês mésolectal, praticado pelas mesmas camadas populacionais. Essa miscigenação linguística firma-se hoje como veículo de expressão em gêneros que vão da música rap ao teatro.

\section{A modo de conclusão: Latinidade e Magrebe}

A linguística e a filologia românica demarcaram algumas diferenças entre os territórios onde se fala um ou vários idiomas derivados do latim. Assim, Badia i Margarit (2007, p. 27-29) considera a existência de uma Romania Continua ou Antiqua à qual pertencem aqueles territórios do sudoeste europeu que fizeram parte do Império Romano e onde se formaram as línguas neolatinas: português, espanhol, francês, catalão, occitano, italiano, romeno e as outras. Entretanto, a extensão atual dessa família linguística na Europa, a Romania Continua ou Antiqua, não coincide com o limes do império de Trajano; houve extensas áreas aonde o latim não chegou a arraigar enquanto em outras foi substituído com o correr dos séculos; esses territórios conformam a Romania Submersa. 
Por fim, a expansão imperialista, política e comercial de alguns povos neolatinos a partir do século XV transplantou várias dessas línguas (fundamentalmente o espanhol, o português e o francês) para amplíssimos espaços que configuram a Romania Nova. A presença das línguas neolatinas no Norte da África se conforma a partir das descontinuidades de sua história; já que faz parte da Romania Submersa, daquelas regiões onde o latim foi substituído por outros idiomas, e da Romania Nova, onde as línguas neolatinas (o francês) foram implantadas como resultado da colonização. Desse modo, podemos fazer um símil entre a latinidade magrebina e uma corrida de relevos que avança descontinuamente sobre a linha do tempo. A descontinuidade ocorre não só no eixo diacrônico, mas também se manifesta na dispersão e nas particularidades dos núcleos latino-falantes instalados na região. A Romania do Norte da África está em contínua renovação, contrastando com a Romania Continua.

Por outra parte, nossa reflexão admite uma leitura complementar: a linha semítica que reúne púnico e árabe como línguas trazidas do Oriente. Nessa pugna pela posse da margem sul do Mediterrâneo entre as duas famílias linguísticas, parece que uma avança ou retrocede sobre a outra de maneira periódica, marcando a terra como as marés através dos séculos, um espaço de tensão e convivência, fértil à hibridação cultural e linguística.

O Mapa $1{ }^{17}$ permite visualizar as manifestações linguísticas e os fatos históricos que balizaram nossa exposição:

\footnotetext{
${ }^{17}$ Este Mapa, documento de minha própria autoria, apresenta uma linha temporal na qual se sobrepõem, por um lado, os fatos históricos determinantes no desenvolvimento das línguas românicas do/no Magrebe e, por outro lado, as variedades linguísticas latinas e neolatinas praticadas ao logo do tempo na região.
} 


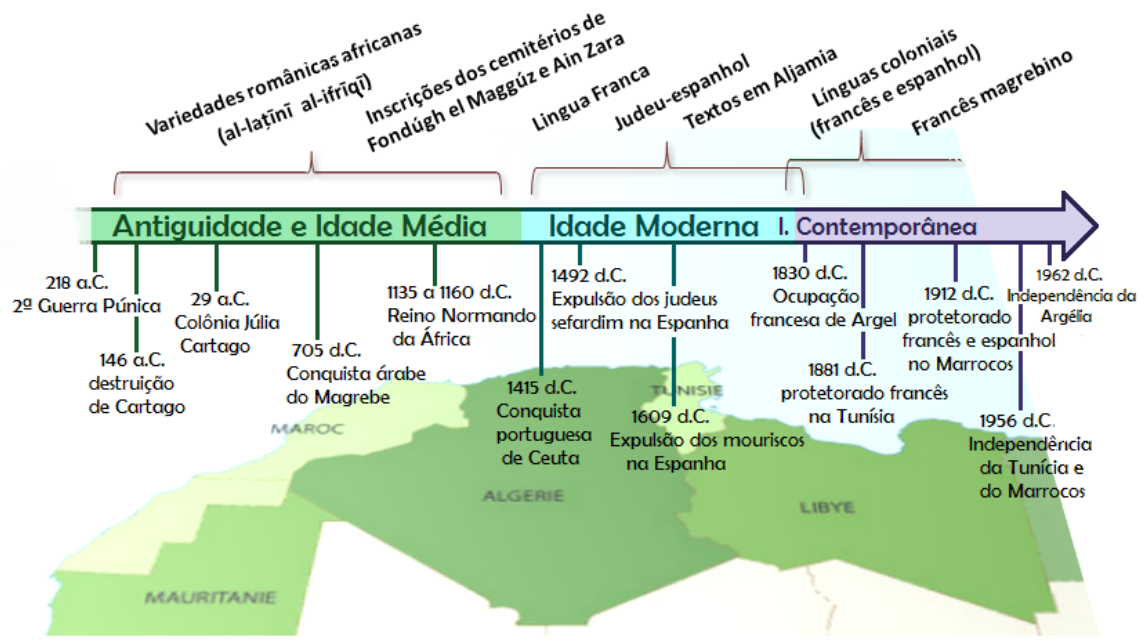

Mapa 1: Eixo espaço-temporal das línguas românicas do/no Mabrebe

À luz dos argumentos examinados, consideramos que essa latinidade africana constitui um legado linguístico, literário e cultural próprio do Magrebe que, em certa medida, quebra a visão da Romania, radicada no Sul da Europa, que desenhou a Romanística no século XIX. Dentro do contexto de mudanças políticas e sociais que os países norteafricanos estão vivendo em diversos modos e graus desde o triunfo da Revolução dos Jasmins na Tunísia em 2011, a Latinidade magrebina abre possibilidades de diálogo não só com seus vizinhos da margem norte do Mediterrâneo, mas com os países africanos francófonos e lusófonos e com a América Latina. Permitindo assim arquitetar paradigmas desde o Sul que superem oposições maniqueístas entre Oriente e Ocidente.

\section{Referências}

ABULFIA, D. Ifriqiyya. In: Enciclopédia federiciana. v. I. Roma: Istituto dell'Enciclopedia italiana Treccani, 2005. Disponível em: $<$ http://www. treccani.it/enciclopedia/ifriqiyya_(Federiciana)>. Acesso em: 12 jan. 2015.

ALVAR, M. El ladino, judeo-español calco. Madrid: Real Academia de Historia, 2000. 
AZOUZI, A. Le français au Maghreb: statut ambivalent d'une langue. Synergies Europe, Paris, n. 3, p. 37-50, 2008.

BADIA I MARGARIT, A. Génesis de la Romania y genio de la romanística. In: GARGALLO, E; BASTARDAS, M. (Org.). Manual de lingüística románica. Barcelona: Ariel, 2007. p. 27-29.

BENZAKOUR, F.; GAADI, D; QUEFFÉLEC, A. Le français au Maroc: lexique et contacts de langues. Bruxelas: AUPELF UREF, 2000.

BOURAS, K. La literatura aljamiada. Aproximación general. In: DIEZ PLAZA. C. et al. (Org.) Actas del I Taller de Literaturas Hispánicas y E/LE. Orã: Instituto Cervantes, 2009. p. 74-88.

BOURDIEU, P. Sociologie de l'Algerie. Paris: Quadrige, 2012.

COUTO, H. A língua franca mediterrânea: histórico, textos e interpretação. Brasília: Plano, 2002.

EPALZA, M; SLAMA-GAFSI, A. El español hablado en Túnez por los moriscos (siglos XVII-XVIII). València: Publicacions de la Universitat de València, 2010.

FANCIULLO, F. Un capitolo della Romania submersa: il latino africano. In: KREMER, D. (Org.). Actes du XVIIIe Congrès Internationalde Linguistique et Philologie Romanes. Trier: Université de Trèves, 1986. p. 162-187.

FANON, F. Los condenados de la tierra. México: Fondo de Cultura Económica, 1963.

HAGÈGE, C. Halte à la mort des langues. Paris: Odile Jacob, 2000.

HUCHON, M. Histoire de la langue française. Paris: Le livre de Poche, 2002.

POSNER, R. Las lenguas romances. Madrid: Cátedra, 1998.

RENZI, L. Introducción a la filología románica. Madrid: Gredos, 1982.

TAGLIAVINI, C. Orígenes de las lenguas neolatinas: introducción a la filología romance. Madrid: Fondo de Cultura Económica, 1993. 